\title{
Neuroendocrine Differentiation in Prostate Cancer: Emerging Biology, Models, and Therapies
}

\author{
Loredana Puca,,${ }^{1,2}$ Panagiotis J. Vlachostergios, ${ }^{2}$ and Himisha Beltran ${ }^{1,2}$ \\ ${ }^{1}$ Englander Institute for Precision Medicine, Weill Cornell Medicine and New York-Presbyterian Hospital, \\ New York, New York 10021 \\ ${ }^{2}$ Division of Medical Oncology, Weill Cornell Medicine, New York, New York 10021 \\ Correspondence: hip9004@med.cornell.edu
}

\begin{abstract}
Although a de novo clinical presentation of small cell neuroendocrine carcinoma of the prostate is rare, a subset of patients previously diagnosed with prostate adenocarcinoma may develop neuroendocrine features in later stages of castration-resistant prostate cancer (CRPC) progression as a result of treatment resistance. Despite sharing clinical, histologic, and some molecular features with other neuroendocrine carcinomas, including small cell lung cancer, castration-resistant neuroendocrine prostate cancer (CRPC-NE) is clonally derived from prostate adenocarcinoma. CRPC-NE therefore retains early prostate cancer genomic alterations and acquires new molecular changes making them resistant to traditional CRPC therapies. This review focuses on recent advances in our understanding of CRPC-NE biology, the transdifferentiation/plasticity process, and development and characterization of relevant CRPC-NE preclinical models.
\end{abstract}

Cellular plasticity plays a pivotal role in driving treatment resistance in cancer. In prostate cancer, a subset of patients initially diagnosed with prostate adenocarcinoma may acquire histologic features of small cell neuroendocrine carcinoma on metastatic biopsy during later stages of disease progression after developing resistance to traditional systemic therapies (Bluemn et al. 2017). These may encompass a spectrum ranging from adenocarcinoma with neuroendocrine differentiation, mixed histologies, and in extreme cases complete transformation to small cell carcinoma, which is morphologically indistinguishable from other small cell cancers (Epstein et al. 2014). Neuroendocrine carcinoma cells in this setting typically show low or absent androgen receptor (AR) expression, express classical neuroendocrine markers, and may harbor genomic features common in other small cell carcinomas such as TP53 and RB1 loss (Beltran et al. 2016a). Clinically, castration-resistant neuroendocrine prostate cancer (CRPC-NE) is associated with aggressive disease, relative resistance to AR-directed therapeutics, and sensitivity to platinum-based chemotherapy. Recent advances in the molecular characterization of CRPC-NE combined with preclinical observations have provided biologic insights into the evolutionary process and have informed the development of new therapeutics

Editors: Michael M. Shen and Mark A. Rubin

Additional Perspectives on Prostate Cancer available at www.perspectivesinmedicine.org

Copyright (C) 2019 Cold Spring Harbor Laboratory Press; all rights reserved; doi: 10.1101/cshperspect.a030593

Cite this article as Cold Spring Harb Perspect Med 2019;9:a030593 
L. Puca et al.

targets for this aggressive subset of advanced prostate cancer.

\section{NEUROENDOCRINE CELLS IN BENIGN PROSTATE AND PROSTATE CANCER}

Neuroendocrine cells (NEs) in the normal prostate gland were first described by Pretl in 1944 as the argentaffin basal cells (Kazzaz 1974). They exist among the prostate-specific antigen (PSA) producing luminal cells and the prostate basal cells, representing only a minor fraction of the epithelial compartment $(<1 \%)$ (Parimi et al. 2014). The exact function of these normal prostatic NEs is not well understood, but they may play a role in supporting the growth of surrounding basal and luminal cells through the secretion of neuropeptides (e.g., calcitonin, serotonin, adrenomedullin, bombesin, and others). In the normal prostate gland, NEs lack the proliferation marker Ki67, appear to be postmitotic, and express antiapoptotic protein Bcl-2 (Bonkhoff et al. 1991, 1995; Nakada et al. 1993).

De novo small cell neuroendocrine carcinoma of the prostate is rare, and these cases are hypothesized to arise from these normal NEs or a multipotent stem cell located within the prostate gland based on the high expression of CD44 (Simon et al. 2009) and other genes related to stemness such as OCT-3/4 and Bmi (Patrawala et al. 2006). Several studies have suggested that NEs can help sustain surrounding prostate adenocarcinoma cellular growth through a paracrine mechanism via their secretory products (i.e., bombesin, serotonin [5-HT], neuron-specific enolase [NSE], a thyroid-stimulating-like peptide [thyroid-stimulating hormone, TSH], somatostatin [SST], parathyroid hormone-related protein [PTHrP]). For instance, bombesin has been shown to increase prostate cancer proliferation (Jongsma et al. 2000) and prevent apoptosis of prostate cancer cells in vitro (Salido et al. 2000). Receptors for various NE products such as serotonin (5HT1a) (Abdul et al. 1994), bombesin/gastrin-releasing peptide (GRP), gastrin-releasing peptide receptor (GRPR) (Markwalder and Reubi 1999), and somatostatin (SSTR1-5) (Dizeyi et al. 2002) are present in both benign prostate and prostate tumors.

\section{INDUCERS OF THE NEUROENDOCRINE PHENOTYPE IN PROSTATE CANCER}

A number of signaling molecules have been shown to trigger the development of neuroendocrine features in prostate adenocarcinoma cells in vitro. Androgen-deprivation therapy (ADT) affects the expression of epithelial markers with a decrease in E-cadherin and gain of mesenchymal markers, such as $\mathrm{N}$-cadherin, vimentin, Zeb1, Twist1, and Snail2 (Sun et al. 2012), toward an epithelial-mesenchymal transition (EMT)-like state. LNCaP cells transfected with Snail undergo neuroendocrine differentiation with neurite-like morphologic characteristics and increased levels of classical NE markers such as neuron specific enolase (NSE) and chromogranin A; subsequent knockdown of Snail in these cells can revert this phenotype (McKeithen et al. 2010). Similar to ADT, loss or silencing of the AR itself with small interfering RNA (siRNA) may also trigger NE properties to LNCaP cells (Wright et al. 2003).

Hypoxia is a characteristic feature of advanced solid tumors and strongly associates with malignant tumor progression and resistance to chemotherapy. Studies have suggested that hypoxia facilitates the malignancy of prostate adenocarcinoma cells by increasing androgen-independence (Yamasaki et al. 2013). Other reports show that hypoxia can induce neuroendocrine programs through down-regulation of Notch signaling (Danza et al. 2012). Hypoxia down-regulates both PTEN and REST in prostate cancer epithelia inducing expression of neuronal genes and microRNAs (miRNAs) associated with neuroendocrine reprogramming (Liang et al. 2014).

The Wnt pathway may also play a role in neuroendocrine transformation of prostate cancer cells through activation of the Wnt pathway effector $ß$-catenin. $\beta$-catenin induces neuroendocrine features in LNCaP cells (Ciarlo et al. 2012). LNCaP cells transfected with Wnt-11 resemble LNCaP cells grown in an androgen-depleted environment. Cells with Wnt-11 overexpression display high levels of the NE markers NSE and ASCL1. LNCaP cells in androgen-free medium and LNCaP cells transfected with Pro- 
tocadherin-PC (PCDH-PC) show higher levels of luciferase $B$-catenin and expression of $\mathrm{Wnt}$ target genes (Uysal-Onganer et al. 2010).

Other inducers of the neuroendocrine phenotype in vitro include MnSOD (QuirosGonzalez et al. 2011; Courel et al. 2014), hASH-1 (Rapa et al. 2013), HB-EGF (Adam et al. 2002), RPTP $\alpha$ (Zhang et al. 2003), and cAMP (Cox et al. 1999). Overall these studies provided early insights into the appearance of neuroendocrine characteristics from adenocarcinoma cells.

\section{REACTIVATION OF STEM CELL, DIFFERENTIATION AND NEURONAL PATHWAYS IN CRPC-NE}

During progression toward the neuroendocrine state, multiple molecular programs are activated conferring neuronal and stem-like characteristics as shown by the CD49f High signature defined by the Witte group. Through the characterization of multiple epithelial cell populations in the human prostate, including basal stem-cell-like prostate cancer cells (CD49f Hi), they found that the small cell/NE prostate cancer transcriptional program is similar to the CD49f Hi program with overexpression of NOTCH, FGFR, WNT pathways (Smith et al. 2015).

The retrotransposon-derived gene PEG10 (paternally expressed 10), a gene normally expressed during placental development is highly expressed in CRPC-NE patient tumors and the LTL331R transdifferentiation patient-derived xenograft (PDX) model (described below). PEG10 promotes cell-cycle progression from G0/G1 in the context of TP53 loss and regulates Snail expression via TGF- $\beta$ signaling to promote invasion. LNCaP cells grown in ligand-depleted media, or treated with enzalutamide, results in PEG10 overexpression that is reversible by adding a synthetic androgen (Akamatsu et al. 2015).

N-MYC (MYCN) is an oncogenic transcription factor in the MYC gene family that includes MYC, MYCL, and MYCN, frequently dysregulated in a number of human cancers (Dang 2012). $\mathrm{N}-\mathrm{MYC}$ is important for neuronal development and drives proliferation of granule neuron pre- cursors derived from neuronal progenitor cells. Overexpression and amplification of N-MYC have been implicated in driving a subset of neuroblastoma, small cell lung cancer, central nervous system (CNS) tumors (Brodeur et al. 1984; Knoepfler et al. 2002), and more recently neuroendocrine prostate cancer. In prostate cancer, NMYC suppresses AR signaling and regulates the CRPC-NE program through transcriptional regulation and cooperation with Aurora kinase A (AURKA), EZH2, and other cofactors (Beltran et al. 2011; Dardenne et al. 2016, Lee et al. 2016).

The repressor element-1 silencing transcription factor (REST), also known as neuron restrictive silencing factor (NRSF), silences the expression of neuron-specific protein coding genes and miRNAs in nonneuronal cells (Ballas et al. 2005). REST down-regulation is observed in up to $50 \%$ of CRPC-NE tumors (Lapuk et al. 2012). LNCAP cells transfected with si-REST overexpress neuronal-associated genes as Syn1, NTRK3, BDNF, and Grin2A (Svensson et al. 2014). REST is a master regulator of hypoxiainduced genes and essential for hypoxia-induced neuroendocrine differentiation of prostate cancer cells (Lin et al. 2016). Recent studies evaluating 155 castration-resistant prostate cancer (CRPC) metastases from 50 patients, 24 prostate cancer PDX models (LuCaP), and a separate cohort of castration-resistant adenocarcinoma (CRPCAdeno) and CRPC-NE patients identified a splicing form of REST induced by the serine/arginine-repetitive matrix 4 (SRRM4) in CRPC-NE. SRRM4 was capable of promoting neuroendocrine differentiation generating an inactive slice variant form of REST, and these effects were further enhanced by loss-of-function of TP53 or RB1 (Zhang et al. 2015; Li et al. 2017). Interleukin-6 expression has also been reported as a suppressor of REST and is involved in resistance to the AR antagonist enzalutamide (Zhu et al. 2014).

The POU-domain transcription factor BRN2 (POU3F2), a master regulator of neuronal differentiation, is highly expressed in AR indifferent preclinical models of enzalutamide resistance and CRPC-NE tumors (Bishop et al. 2016). BRN2 is directly transcriptionally repressed by the AR. Therefore, in the setting of loss of AR 
L. Puca et al.

signaling, BRN2 is up-regulated. BRN2 is capable of driving expression of SOX 2 and promoting the neuroendocrine phenotype (Bishop et al. 2016).

LNCAP-AR infected with short hairpins against RB1 and TP53 also showed up-regulation of SOX 2 together with increased expression of basal markers (CK5, CK14, and TP63) and neuroendocrine markers (SYP, CHGA) $(\mathrm{Mu}$ et al. 2017). Complete silencing of SOX 2 in this LNCAP-AR shRB1/TP53 tumor model restores the sensitivity to enzalutamide in vivo, suggesting that SOX2 is a driver of lineage plasticity. The forkhead box protein A2 (FOXA2) has been shown to be up-regulated in mouse models that recapitulate CRPC-NE phenotype NMYC/AKT1 and TRAMP (Lee et al. 2016; Chiaverotti et al. 2008). In the TRAMP model, FOXA2 cooperates with hypoxia-inducible factor 1 alpha (HIF1 alpha) to induce genes as HES6, SOX9, and KDM3A involved in neuroendocrine differentiation (Qi et al. 2010). FOXA2 has been found highly expressed in $75 \%$ of small cell neuroendocrine prostate cancer patients analyzed by immunohistochemistry suggesting that it could be a marker for neuroendocrine tumors (Park et al. 2017) (Table 1).

\section{GENOMIC ALTERATIONS IN CRPC-NE}

Mutation or deletions involving the $R B 1$ and TP53 genes are commonly observed in highgrade/small cell neuroendocrine carcinomas and are universally lost in small cell lung cancers (George et al. 2015). The combination of $R B 1$ and TP53 loss can drive a small cell phenotype in lung and prostate cancer models (Greenberg et al. 1995; Gingrich et al. 1996; Zhou et al. 2006; Meder et al. 2016), suggesting they are important factors in the pathogenesis of NE tumors. $R B 1$ and TP53 alterations are enriched in patients with CRPC-NE compared with castration-resistant prostate adenocarcinoma (Hansel et al. 2009; Williamson et al. 2011; Tan et al. 2014). In a cohort of 81 patients with CRPC (51 CRPC-Adeno, 30 CRPC-NE), RB1 loss was present in $70 \%$ of CRPC-NE versus $32 \%$ CRPC-Adeno, mutation or deletion of TP53 in $66.7 \%$ of CRPC-NE versus $31.4 \%$ of CRPCAdeno (Beltran et al. 2016a). Recent analysis of the International Stand Up to Cancer (SU2C)Prostate Cancer Foundation (PCF) Dream Team advanced prostate cancer patient cohort showed that these alterations are also present in a subset of CRPC-Adeno (Robinson et al. 2015; Armenia et al. 2018). Analyses of other patient cohorts, including the ones from Johns Hopkins and University of Michigan, has shown that $R B 1$ loss is correlated with cyclin D1 protein down-regulation and overexpression of p16 (Tsai et al. 2015). High p16/CCND1 ratio was sufficient to distinguish prostatic small-cell carcinomas from adenocarcinomas (Tsai et al. 2015). TP53 alterations are also frequently associated with PTEN loss in CRPC patients (23\% cooccurrence) (Robinson et al. 2015). Loss of PTEN and TP53 has been associated with abiraterone resistance and progression towards a small cell/ neuroendocrine phenotype in genetically engineered (GEM) models (Zou et al. 2017).

The deubiquinating enzyme CYLD (cylindromatosis) is deleted in up to half of CRPCNE (Beltran et al. 2016a). This enzyme has been reported as negative regulator of $\mathrm{NF}-\mathrm{\kappa B}$ activation acting as tumor suppressor (Harhaj and Dixit 2011). CYLD is a crucial regulator of diverse cellular processes, such as immune responses, inflammation, death, and proliferation (Massoumi et al. 2010; Sun et al. 2010), and in prostate cancer, loss of CYLD has been correlated with decreased AR messenger RNA (mRNA) expression. Although silencing CYLD showed a decrease in expression of AR-signaling genes, dysregulation of CYLD was not sufficient to induce the transdifferentiation of LNCaP cells, suggesting that additional factors are required (Beltran et al. 2016a).

The TMPRSS2-ERG gene rearrangement, an early event in prostate cancer, is present in $\sim 50 \%$ of CRPC-NE (Tomlins et al. 2005; Mertz et al. 2007; Mosquera et al. 2009; Lotan et al. 2011), at a similar frequency as prostate adenocarcinoma. As opposed to TMPRSS2$E R G$ fusion-positive prostate adenocarcinomas in which ERG protein is overexpressed (Tomlins et al. 2005; Park et al. 2014), ERG may not be overexpressed in TMPRSS2-ERG-positive CRPCNE tumors as ERG protein expression is driven by its androgen-driven partner TMPRSS2, and 
Table 1. Summary of reported genes and pathways implicated in CRPC-NE progression

\begin{tabular}{|c|c|c|}
\hline $\begin{array}{l}\text { Key pathway/ } \\
\text { gene }\end{array}$ & Summary of findings & Reference(s) \\
\hline $\begin{array}{l}\text { MYCN/ } \\
\text { AURKA }\end{array}$ & $\begin{array}{l}\text { MYCN/AURKA (Aurora kinase A) are frequently } \\
\text { overexpressed/amplified in CRPC-NE. LNCaP cells } \\
\text { stably transfected with N-MYC show enhanced in vitro } \\
\text { sensitivity to the Aurora kinase inhibitors }\end{array}$ & $\begin{array}{l}\text { Beltran et al. 2011; Dardenne et al. } \\
\text { 2016, Lee et al. } 2016\end{array}$ \\
\hline$E Z H 2$ & $\begin{array}{l}\text { EZH2 (Enhancer of zeste homolog 2) mRNA is twofold } \\
\text { higher in the CRPC-NE patient cohort compared to } \\
\text { CRPC-Adeno and interacts with AR and NMYC } \\
\text { regulating the NMYC and AR transcriptional } \\
\text { programs. EZH2 inhibitor restores enzalutamide } \\
\text { sensitivity in models of lineage plasticity (LNCaP-AR } \\
\text { sh-RB1/sh-TP53, TKO, DKOCr) }\end{array}$ & $\begin{array}{l}\text { Beltran et al. 2016a; Dardenne et al. } \\
\text { 2016, Clermont et al. 2015; } \mathrm{Mu} \\
\text { et al. } 2017\end{array}$ \\
\hline PEG10 & $\begin{array}{l}\text { PEG10 (Paternally Expressed 10) is overexpressed in } \\
\text { CRPC-NE patient samples and in the LTL331R PDX. } \\
\text { LNCaP cells grown in ligand-depleted media, or } \\
\text { treated with enzalutamide, results in increased PEG10 } \\
\text { expression }\end{array}$ & $\begin{array}{l}\text { Clermont et al. 2015; Akamatsu et al. } \\
2015\end{array}$ \\
\hline $\begin{array}{l}\text { PTEN/AKT } \\
\text { pathway }\end{array}$ & $\begin{array}{l}\text { PTEN deletions are present in } ~ 50 \%-60 \% \text { of CRPC-NE } \\
\text { patients. Activation of AKT by IGF- } 1 \text { leads to } \\
\text { neuroendocrine differentiation in LNCaP and DU145 } \\
\text { prostate cancer cell lines }\end{array}$ & Wu et al. 2007; Tan et al. 2014 \\
\hline $\begin{array}{l}\text { TMPRSS2- } \\
\quad \text { ERG }\end{array}$ & $\begin{array}{l}\text { TMPRSS2-ERG gene rearrangement is reported in 50\% } \\
\text { of CRPC-NE cases. ADT in TMPRSS2:ERG positive } \\
\text { prostate cells causes down-regulation of ERG } \\
\text { expression and increases neuroendocrine gene } \\
\text { expression }\end{array}$ & $\begin{array}{l}\text { Tomlins et al. 2005; Mosquera et al. } \\
\text { 2009; Lotan et al. 2011; Mounir } \\
\text { et al. } 2015\end{array}$ \\
\hline RB1/TP53 & $\begin{array}{l}R B 1 \text { loss and mutations or deletions of TP53 are detected } \\
\text { in the majority of CRPC-NE. } R B 1 \text { loss is highly } \\
\text { correlated to Cyclin D1 protein down-regulation and } \\
\text { overexpression of p16/CDKN2A. RB1 and TP53 loss } \\
\text { support ADT resistance phenotype and lineage } \\
\text { plasticity }\end{array}$ & $\begin{array}{l}\text { Tan et al. 2014; Tsai et al. 2015; } \\
\text { Beltran et al. 2016a; Ku et al. 2017; } \\
\text { Mu et al. } 2017\end{array}$ \\
\hline SOX2/SOX 11 & $\begin{array}{l}\text { SOX2 is up-regulated in } R B 1 \text { and TP53 deleted tumors } \\
\text { and it is required for lineage plasticity } \\
\text { SOX11 is up-regulated in CRPC-NE tumors and its } \\
\text { down-regulation causes down-regulation of } \\
\text { neuroendocrine markers }\end{array}$ & Mu et al. 2017; Zou et al. 2017 \\
\hline$B R N 2$ & $\begin{array}{l}\text { BRN2 or POU3F2 (POU Class } 3 \text { Homeobox 2) is highly } \\
\text { expressed in CRPC-NE and metastatic CRPC-Adeno } \\
\text { with low circulating PSA. BRN2 drives the expression } \\
\text { of the terminal neuroendocrine markers and SOX2 } \\
\text { and it is transcriptionally repressed by AR }\end{array}$ & Bishop et al. 2016 \\
\hline$C Y L D$ & $\begin{array}{l}\text { CYLD (Cylindromatosis) is deleted in } \sim 50 \% \text { of CRPC- } \\
\text { NE samples and its loss has been associated to } \\
\text { decreased AR mRNA expression }\end{array}$ & Beltran et al. 2016a \\
\hline
\end{tabular}


L. Puca et al.

Table 1. Continued

\begin{tabular}{|c|c|c|}
\hline $\begin{array}{l}\text { Key pathway/ } \\
\text { gene }\end{array}$ & Summary of findings & Reference(s) \\
\hline$S P D E F$ & $\begin{array}{l}\text { SPDEF (SAM Pointed Domain Containing ETS } \\
\text { Transcription Factor) is underexpressed and } \\
\text { hypermethylated in CRPC-NE patient cohort. SPDEF } \\
\text { overexpression in prostate epithelium reduces tumor } \\
\text { cell proliferation in vivo and in vitro }\end{array}$ & $\begin{array}{l}\text { Cheng et al. 2014; Beltran et al. } \\
\text { 2016a; Tsui et al. } 2016\end{array}$ \\
\hline REST & $\begin{array}{l}\text { REST (RE1 silencing transcription factor) down- } \\
\text { regulation is observed in } 50 \% \text { of CRPC-NE tumors and } \\
\text { it is essential for hypoxia-induced neuroendocrine } \\
\text { differentiation of prostate cancer cells. LNCaP cells } \\
\text { transfected with si-REST overexpress neuronal } \\
\text { associated genes as Syn1, NTRK3, BDNF and Grin } 2 A\end{array}$ & $\begin{array}{l}\text { Lapuk et al. 2012; Svensson et al. } \\
2014\end{array}$ \\
\hline SRRM4 & $\begin{array}{l}\text { SRRM4 (Serine/arginine repetitive matrix 4) promotes } \\
\text { neuroendocrine differentiation by generating an } \\
\text { inactive slice variant form of REST }\end{array}$ & Li et al. 2016 \\
\hline FOXA2 & $\begin{array}{l}\text { The forkhead box protein A2 (FOXA2) is highly } \\
\text { expressed in NMYC/AKT1 and TRAMP model and } \\
\text { in } 75 \% \text { of patients with small cell neuroendocrine } \\
\text { prostate cancer analyzed by immunohistochemistry. It } \\
\text { cooperates with HIF1 } \alpha \text { to induce genes involved in } \\
\text { neuroendocrine differentiation as HES6, SOX9, } \\
\text { KDM3A }\end{array}$ & $\begin{array}{l}\text { Lee et al. 2016; Chiaverotti et al. 2008; } \\
\text { Park et al. } 2017 \text { Qi et al. } 2010\end{array}$ \\
\hline
\end{tabular}

CRPC-NE, castration-resistant neuroendocrine prostate cancer; AR, androgen receptor; DKOCr, double knockout castrated; TKO, triple knockout; PDXs, patient-derived xenografts; IGF-1, insulin-like growth factor-1; ADT, androgen-deprivation therapy; CRPC-Adeno, castration-resistant adenocarcinoma; si, small interfering; sh, short-harpin; HIF1 $\alpha$, hypoxiainducible factor $1 \alpha$.

AR signaling is often low in CRPC-NE (Beltran et al. 2011). ERG is a transcription factor involved in embryonic development, cell cycle control, cell proliferation, differentiation, migration, and angiogenesis (Adamo and Ladomery 2016). Recent studies have implicated loss of ERG protein expression itself in TMPRSS2: $E R G$-positive prostate cells may be a key mediator of the dedifferentiation process important for CRPC-NE progression (Mounir et al. 2015).

\section{EPIGENOMIC ALTERATIONS}

In addition to genomic changes, significant differences have been reported between the DNA methylation profiles of CRPC-Adeno and CRPC-NE tumors with epigenetically dysregulated genes involved in neuronal and developmental programs (Beltran et al. 2016a; Kleb et al. 2016). A significantly hypermethylated and underexpressed gene in the CRPC-NE cohort (Beltran et al. 2016a) was the tumor suppressor gene SPDEF (prostate-derived Ets factor). SPDEF overexpression in prostate epithelium has been shown to reduce tumor cell proliferation in vivo and in vitro (Cheng et al. 2014). SPDEF also modulates the epithelial-to-mesenchymal transition by up-regulating E-cadherin expression and down-regulating the expression of N-cadherin, SNAIL, SLUG, and vimentin (Tsui et al. 2016). In CRPC-NE, hypermethylation of SPDEF is associated with up-regulation of mesenchymal markers (Beltran et al. 2016a).

The histone methyltransferase EZH2 is highly expressed in CRPC-NE (more than twofold increase compared with CRPC) (Beltran et al. 2011, 2016; Clermont et al. 2015, Kleb et al. 2016), and may be involved in coordinating the transcriptional pathways that are activated during neuroendocrine transdifferentiation 
and, therefore, regulating tumor plasticity. Recent models with Pten and Rb1 losses (PBCre4: $\left.\operatorname{Pten}^{\mathrm{f} / \mathrm{f}}: \mathrm{Rb} 1^{\mathrm{f} / \mathrm{f}}, \mathrm{DKO}\right)$ and Pten $R b 1$ and Trp53 losses (PBCre4:Pten ${ }^{\mathrm{f} / \mathrm{f}}: \mathrm{Rb}^{\mathrm{f} / \mathrm{f}}: \operatorname{Trp} 53^{\mathrm{f} / \mathrm{f}}$, TKO) showed up-regulation of EZH2 together with appearance of neuroendocrine features. Silencing of EZH2 in cells derived by castration-resistant DKO tumors resulted in an increased expression of $\mathrm{AR}$ and luminal markers and a decrease of SYP-positive cells (Ku et al. 2017) (Table 1).

\section{PRECLINICAL MODELS}

Multiple preclinical models have been established to understand mechanisms of neuroendocrine transdifferentiation and develop therapeutic targets for CRPC-NE. Each model displays unique features that contribute to the comprehension of this phenotype.

\section{Cell Lines}

The NCI-H660 cell line (ATCC CRL-5813) was derived from a lymph node metastasis of a 63 yr-old patient diagnosed with small cell carcinoma. Initially classified as small cell lung cancer, this cell line was later reclassified as prostate origin based on the presence of the prostate cancer-specific TMPR22-ERG gene fusion (Mertz et al. 2007). NCI-H660 cells lack AR expression and express classical neuroendocrine markers (SYP, CD56, NSE). A number of studies have used the NCI-H660 cell line to test gene expression profiles and therapies both in vitro and in vivo. For instance, NCI H66O was used to study the function of TP53 deletion/mutation in NEPC. Knocking down P53 in NCI-H660 resulted in enhanced AURKA expression ( $\mathrm{Li}$ et al. 2015). NCI-H660 shows sensitivity to EZH2 inhibitors compared with adenocarcinoma cell lines, and NCI-H660 xenografts are sensitive to AURKA inhibition (Beltran et al. 2011, 2016b).

The PC3 cell line was derived from a bone metastasis of a patient with prostate cancer (Kaighn et al. 1979) and has been proposed as a model of CRPC-NE (Tai et al. 2011). Multiple sublines of the PC3 cell line have been developed that show increases in metastatic ability when transplanted in mice. Although derived from adenocarcinoma, PC3 cell line proliferation is independent of androgen, and PC3 lacks expression of AR or PSA mRNA/protein, expresses CD44 and neuroendocrine markers NSE and chromogranin A (Tai et al. 2011), and it is PTEN deficient. Therefore, PC3 has been used to address questions about the neuroendocrine phenotype in comparison with the androgensensitive LNCaP cell line (Marchiani et al. 2010).

$22 \mathrm{Rv} 1$ is a cell line that was derived by serial passaging of the xenograft CWR22R, isolated from a patient with prostate adenocarcinoma with bone metastases after repeated tumor regression and relapse under castrated condition (Sramkoski et al. 1999). The 22Rv1 cell line expresses AR mRNA/protein and PSA at the mRNA level, but not at the protein level, and these cells have some overlapping features of neuroendocrine prostate cancer. Although they are androgen sensitive (Chlenski et al. 2001), when maintained under hypoxia for a few days these cells up-regulate the NE marker NSE and develop neurite-like structures. This cell line when implanted in mice expresses NE markers within highly hypoxic tumorigenic regions (Qi et al. 2010) (Table 2).

\section{Mouse Models}

The transgenic adenocarcinoma of the mouse prostate (TRAMP) model was derived from C57BL/6 inbred mice, expressing the rat probasin promoter (androgen and zinc dependent) that drives the expression of SV40 T-antigen (SV40Tag) transgene. The SV40-Tag induces oncogenic progression by binding to and inactivating the Trp53 and Rb1 tumor suppressors. TRAMP mice develop tumors that metastasize frequently to the lymph nodes and lungs. High-grade PIN (prostatic intraepithelial neoplasia) is found in the prostates of this model after 10-16 wk. This model develops poorly differentiated neuroendocrine tumors at 24 wk (Greenberg et al. 1995; Gingrich et al. 1996). Pten loss increases the rate of cancer progression in the TRAMP model (Kwabi-Addo et al. 2001). TRAMP has been used for testing chemotherapeutics during prostate cancer progression (Tang et al. 2009). This model 
L. Puca et al.

Table 2. Preclinical models of CRPC-NE

\begin{tabular}{|c|c|c|c|}
\hline CRPC-NE models & Sources & Features & Reference(s) \\
\hline $\begin{array}{l}\text { NCI-H660 cell line } \\
\quad(\text { ATCC CRL-5813) }\end{array}$ & Lymph node metastasis & $\begin{array}{l}\text { Loss of the } A R \text { locus on chromosome } \\
\text { X. Lack of sensitivity to androgen } \\
\text { deprivation treatment. Harbors } \\
\text { TMPRSS2-ERG gene fusion, expresses } \\
\text { synaptophysin, CD56, NSE }\end{array}$ & Mertz et al. 2007 \\
\hline $\begin{array}{l}\text { PC3 (ATCC } \\
\text { CRL-1435) }\end{array}$ & Bone metastasis & $\begin{array}{l}\text { Androgen-independent, lacks AR and } \\
\text { PSA messenger RNA (mRNA) and } \\
\text { protein expression and is PTEN } \\
\text { deficient. Expresses CD44 and } \\
\text { neuroendocrine markers NSE and } \\
\text { chromogranin A }\end{array}$ & $\begin{array}{l}\text { Kaighn et al. } \\
\text { 1979; } \\
\text { Marchiani } \\
\text { et al. 2010; Tai } \\
\text { et al. 2011 }\end{array}$ \\
\hline $\begin{array}{l}\text { 22Rv1 (ATCC } \\
\text { CRL-2505) }\end{array}$ & $\begin{array}{l}\text { Serial passaging of the } \\
\text { xenograft CWR } 22 \mathrm{R} \\
\text { after castration-induced } \\
\text { tumor regression and } \\
\text { relapse }\end{array}$ & $\begin{array}{l}\text { Androgen-sensitive, expresses AR and } \\
\text { PSA mRNA/protein. Up-regulation of } \\
\text { the neuroendocrine marker NSE. } \\
\text { Protrusion of neurite-like structures } \\
\text { under hypoxic conditions }\end{array}$ & $\begin{array}{l}\text { Sramkoski } \\
\text { et al. 1999; } \\
\text { Chlenski et al. } \\
\text { 2001; Qi et al. } \\
\text { 2010 }\end{array}$ \\
\hline TRAMP & $\begin{array}{l}\text { C57BL/6 mice expressing } \\
\text { the rat probasin driving } \\
\text { the expression of SV40 } \\
\text { large and small T } \\
\text { antigens in prostatic } \\
\text { epithelial cells }\end{array}$ & $\begin{array}{l}\text { Poorly differentiated neuroendocrine } \\
\text { tumors by } 24 \text { weeks of age }\end{array}$ & $\begin{array}{l}\text { Greenberg et al. } \\
\text { 1995; } \\
\text { Gingrich } \\
\text { et al. } 1996\end{array}$ \\
\hline$p 53^{\mathrm{PE}-1-} ; R b^{\mathrm{PE}-1-}$ & $\begin{array}{l}\text { GEM model of } R b 1 / \operatorname{Trp} 53 \\
\text { co-deletion from the } \\
\text { mouse prostate }\end{array}$ & $\begin{array}{l}\text { Poorly differentiated phenotype with } \\
\text { neuroendocrine features by } \sim 32 \text { weeks } \\
\text { of age }\end{array}$ & Zhou et al. 2006 \\
\hline
\end{tabular}

$\begin{aligned} \text { PBCre4:Pten } & f / f: R b 1^{f / f} \quad \text { GEM model with knock } \\ & \text { out of Pten and } R b 1 \text { in } \\ & \text { mouse prostate } \\ & \text { epithelium }\end{aligned}$

PBCre4:Pten ${ }^{f / f}: R b 1^{f / f}:$ GEM model with knock $\operatorname{Trp} 53^{f / f}$ out of Pten, Rb1 and Trp53 in mouse prostate epithelium

\begin{tabular}{|c|c|}
\hline $\begin{array}{l}\text { Nkx3.1 }{ }^{\text {CreERT2/+ }} \\
\text { Pten }^{\text {flox/flox }} ; \\
\operatorname{Trp}^{\text {flox/flox }} \\
\text { (NPp53 mice) }\end{array}$ & $\begin{array}{l}\text { GEM model with Trp53 } \\
\text { and Pten deletion in } \\
\text { mouse prostate } \\
\text { epithelium }\end{array}$ \\
\hline
\end{tabular}

Develops PIN lesions and adenocarcinoma within 12 weeks, synaptophysin positive cells appear by week 25. Median survival 38 weeks. Develops metastases in lymph node, liver, and lung

Develops castration-resistant tumors, survival rate of 16 weeks not extended with castration. Low levels of AR and overexpression of EZH2, SOX2, chromogranin A and synaptophysin

Develops features of CRPC-Adeno under castrate conditions. Treatment with abiraterone results in the appearance of neuroendocrine features. Low levels of AR and epithelial cytokeratins, high level of Ki67, and overexpression of synaptophysin
Zou et el. 2017

Ku et al. 2017

Ku et al. 2017

K

K

Kaighn et al. Marchiani et al. 2010; Tai 
Table 2. Continued

\begin{tabular}{|c|c|c|c|}
\hline CRPC-NE models & Sources & Features & Reference(s) \\
\hline$M Y C N$-myrAKT1 & $\begin{array}{l}\text { Human prostate basal cells } \\
\text { with NMYC induction } \\
\text { and AKT1 activation } \\
\text { implanted in NSG mice }\end{array}$ & $\begin{array}{l}\text { Develops tumors at } 6-10 \text { weeks. Low } \\
\text { levels of AR and low androgen- } \\
\text { regulated genes, expresses } \\
\text { chromogranin, synaptophysin }\end{array}$ & Lee et al. 2016 \\
\hline $\begin{array}{l}\text { T2-Cre }{ }^{+/+} ; \text {Pten }^{\mathrm{f} / \mathrm{f}} ; \\
L S L-M Y C N^{+/+}\end{array}$ & $\begin{array}{l}\text { GEM model with } M Y C N \\
\text { gene induction and Pten } \\
\text { deletion }\end{array}$ & $\begin{array}{l}\text { Highly invasive tumors display foci of } \\
\text { AR-positive adenocarcinoma and } \\
\text { poorly differentiated sarcomatoid foci. } \\
\text { The NMYC gene expression signature } \\
\text { derived from these tumors resembles } \\
\text { the one of the CRPC-NE human } \\
\text { cohort }\end{array}$ & $\begin{array}{l}\text { Dardenne et al. } \\
2016\end{array}$ \\
\hline LUCAP 49 PDXs & Omental metastasis & $\begin{array}{l}\text { Androgen-insensitive, lacks expression } \\
\text { of PSA or AR, increased expression of } \\
\text { synaptophysin and NSE. Highly } \\
\text { aggressive, rapid growth in mice, } \\
>75 \% \text { of nuclei positive for Ki67 }\end{array}$ & True et al. 2002 \\
\hline MDA PCA 144 PDXs & Pelvic exenteration & $\begin{array}{l}\text { Intense staining of chromogranin, } \\
\text { synaptophysin, CD56, and negative } \\
\text { for AR, PSA, PAP, and AMACR. High } \\
\text { proliferation index with Ki67 } \\
\text { positivity in }>90 \% \text { of nuclei. } \\
\text { TMPRSS2:ERG gene fusion is detected }\end{array}$ & $\begin{array}{l}\text { Aparicio et al. } \\
2011\end{array}$ \\
\hline WISH-PC2 PDXs & $\begin{array}{l}\text { Transuretheral resection of } \\
\text { the prostate }\end{array}$ & $\begin{array}{l}\text { Lacks AR, PSA, PSMA, expresses } \\
\text { chromogranin A, NSE, and } \\
\text { synaptophysin, mutated form of TP53, } \\
\text { overexpression of the anti-apoptotic } \\
\text { protein BCL2. High proliferative } \\
\text { index. }\end{array}$ & $\begin{array}{l}\text { Pinthus et al. } \\
2000\end{array}$ \\
\hline $\begin{array}{l}\text { LTL352 and LTL370 } \\
\text { PDXs }\end{array}$ & $\begin{array}{l}\text { Urethral metastasis } \\
\text { (LTL352) and penile } \\
\text { metastasis (LTL370) }\end{array}$ & $\begin{array}{l}\text { Lacks AR and PSA expression, intense } \\
\text { staining for chromogranin and } \\
\text { synaptophysin. TMPRSS2:ERG gene } \\
\text { fusion is detected }\end{array}$ & Lin et al. 2014 \\
\hline $\begin{array}{l}\text { MSK-PCA4 } \\
\text { Organoids }\end{array}$ & Pleural effusion & $\begin{array}{l}\text { Small cell features with high proliferation } \\
\text { index, negative for AR, positive for } \\
\text { synaptophysin }\end{array}$ & Gao et al. 2014 \\
\hline $\begin{array}{l}\text { OWCM CRPC-NE } \\
\text { organoids }\end{array}$ & $\begin{array}{l}\text { Lymph node, pelvic mass, } \\
\text { liver, bone biopsies }\end{array}$ & $\begin{array}{l}\text { Neuroendocrine features with small- to } \\
\text { medium-sized round cells, fine } \\
\text { chromatin pattern, and some nuclear } \\
\text { molding. Lacks AR expression, } \\
\text { expresses chromogranin, } \\
\text { synaptophysin, and CD56. }\end{array}$ & Puca et al. 2017 \\
\hline
\end{tabular}

CRPC-NE, castration-resistant neuroendocrine prostate cancer; AR, androgen receptor; NSE, neuron-specific enolase; GEM, genetically modified mouse; PIN, prostatic epithelial neoplasia; CRPC-Adeno, castration-resistant adenocarcinoma; NOD-SCID, nonobese diabetic severe combined immunodeficiency; PSCA, prostate stem cell antigen; PSMA, prostate-specific membrane antigen; PAP, Prostatic Acid Phopshatase; PSA, Prostate-specific antigen; AMACR, alpha-methylacyl CoA racemase; NSG, NOD scid gamma; TRAMP, transgenic adenocarcinoma of the mouse prostate. 
L. Puca et al.

may be useful to study the evolution of the tumor and therapies that can be adopted at different stages of the disease, including CRPC-NE.

In a conditional knockout model $\left(p 53^{\mathrm{PE}-/}\right.$; $\left.R b^{\mathrm{PE}-1-}\right), \operatorname{Tr} p 53$ and $R b 1$ have been knocked out from the mouse prostate epithelium using a prostate-specific expression of a CRE recombinase under the direction Arr2pb promoter (Zhou et al. 2006). These mice develop PIN lesions in $8 \mathrm{wk}$ and by week 32 they show a poorly differentiated phenotype with neuroendocrine features (Zhou et al. 2006). The appearance of this phenotype is strict to both $\operatorname{Trp} 53$ and $R b 1$ losses because inactivation of either Trp53 and $R b 1$ in mouse prostate generate PIN lesions with no further tumor development, suggesting that the synergistic inactivation of $\operatorname{Trp53}$ and $R b 1$ may be needed for neuroendocrine differentiation in these mice. However, in more recently reported GEM models described below, either Trp53 or Rb1 in the setting of Pten loss may also develop neuroendocrine features, accelerated with an additional hit.

As reported by $\mathrm{Ku}$ et al. (2017), PBCre4: Pten $^{\mathrm{f} / \mathrm{f}}: R b 1^{\mathrm{f} / \mathrm{f}}$ (DKO) mice developed PIN lesions by $12 \mathrm{wk}$, had shorter survival compared with single knockout models ( 38 wk vs. 48 wk), distant metastasis (lymph node lung and liver), and showed heterogeneous levels of AR and Cytokeratin 8 (CK8). Cells expressing the neuroendocrine marker synaptophysin appeared by 2025 wk of age. Surgical castration of these mice extended survival by $>48 \mathrm{wk}$, suggesting that they were ADT sensitive. DKO tumors that relapsed after castration showed a significant reduction of $\mathrm{AR}$ expression and spontaneous Trp53 mutations (V173M,R282Q). This model highlighted $R b 1$ loss as enhancer of lineage plasticity initiated by Pten loss.

The authors, as a consequence of spontaneous Trp53 mutations found in DKO castrated tumors, developed another GEM model harboring PBCre4:Pten ${ }^{f / f}$ : Rb1 $1^{f / f}$ :Trp53 ${ }^{f / f}$ (TKO mice). These TKO mice had a survival rate of $16 \mathrm{wk}$, developing a very aggressive phenotype with metastasis in lung, liver, and bone. Castration did not extend the survival rate, suggesting that these tumors were ADT insensitive. TKO tumors showed very low AR expression and patchy synaptophysin positivity (Ku et al. 2017).

Recently, Zou and colleagues (2017) established inducible GEM models for CRPCNE with Trp53 and Pten loss, Pten ${ }^{\text {flox/flox; }}$ Trp53 ${ }^{\text {flox/flox }}$ mice (NPp53 mice) using Nkx3.1 $1^{\text {CreERT2 }}$ as driver. This model has been compared with a previously described Nkx3.1 ${ }^{\text {CreERT2/+ }}$; Pten ${ }^{\text {flox/flox }}$ mouse (NP mice) (Floc'h et al. 2012). NPp53 model as NP mice developed features of CRPC-Adeno in castrated conditions but treatment with the drug abiraterone, an androgen synethesis inhibitor, resulted in a significant reduction of tumor volume in NP mice, whereas castrated NPp53 tumor growth was not inhibited. In some NPp53 mice, abiraterone treatment supported the progression of the tumor, as well as the appearance of neuroendocrine features with reduced expression of AR, reduction of epithelial cytokeratins, high level of proliferation, and up-regulation of synaptophysin (Zou et al. 2017).

Lee and colleagues engineered human basal epithelial prostate cells with AKT1, a gene frequently activated in prostate cancer, including CRPC-NE (Conley-LaComb et al. 2013) and NMYC by lentiviral transduction. N-MYC-AKT1 epithelial cells were mixed with mouse urogenital sinus mesenchyme (UGSM) and implanted subcutaneously in NSG. These mice developed tumors after 6-10 wk. These tumors consisted of high-grade adenocarcinoma with regions of neuroendocrine features, including high nuclear-to-cytoplasmic ratio, frequent mitotic figures with low levels of expression of $\mathrm{AR}$, and the androgen-regulated genes $N K X 3-1, K L K 3$, and TMPRSS2, and expression of the neuroendocrine markers CHGA, SYP, NCAM1, and NSE. The AURKA inhibitor CD532 reduced N-MYC protein expression in this model, and substantially slowed tumor growth in vivo (Lee et al. 2016).

Dardenne et al. generated GEM mice that carry human $M Y C N$ gene integrated into the ROSA26 (LSL-MYCN) locus and a Tmprss2driven tamoxifen-activated Cre recombinase to drive its expression in luminal prostate cells. These mice also harbored a Pten conditional knockout allele. After induction with tamoxifen, $\mathrm{N}-\mathrm{MYC}$ was overexpressed and, in the context 
of Pten loss, led to focal mouse high-grade prostatic intraepithelial neoplasia (mHGPIN) at 3 mo postinduction. At 9 mo postinduction, N-MYC overexpressed tumors were highly invasive, displaying foci of AR-positive adenocarcinoma and poorly differentiated foci overexpressing the mesenchymal marker vimentin, no pancytokeratin expression, and variable levels of AR expression. The N-MYC gene expression signature derived from these tumors resembled the one of CRPC-NE human cohort (Dardenne et al. 2016).

\section{Lineage Plasticity and Transdifferentiation}

Clinical data, including genomic analyses of metastatic tumors, have supported an evolution of CRPC-NE from a prostate adenocarcinoma precursor. Recent preclinical studies have shed further light on the origin of CRPC-NE and the mechanisms driving this evolutionary process. Two concepts have been formulated by the authors supported by GEM mouse models: $\mathrm{Ku}$ et al. (2017) and $\mathrm{Mu}$ et al. (2017) define the concept of "lineage plasticity" as a transition state in which cells are in a multilineagestem-like state that can be reverted or sealed by treatment pressure. Zou and colleagues define the "transdifferentiation" process in which a luminal adenocarcinoma cell transforms into an NE acquiring a new transcriptional program.

$\mathrm{Ku}$ and colleagues observed the existence of cellular heterogeneity with both luminal-like $\mathrm{Krt}^{\text {high }}$ Syp $^{\text {low }}$ cells and neuroendocrine-like Krt8 $8^{\text {low }}$ :Syp ${ }^{\text {high }}$ cells within DKO primary and metastatic tumors. They incorporated the Brainbow 2.1 lineage tracing allele into DKO mice, and observed that all the end-stage tumors were monocolor, suggesting that these heterogeneous DKO tumors, both primary and metastatic, were likely derived from a single neoplastic cell clone. Moreover, the early Syp ${ }^{\text {high }}: \mathrm{Krt}^{\text {low }}$ foci still expressed AR consistent with the derivation of Krt8 ${ }^{\text {low }}:$ Syp ${ }^{\text {high }}$ cells from preexisting Krt8 ${ }^{\text {high }}:$ Syp ${ }^{\text {low }}$ tumor. The authors defined the transcription factor SOX2 as main driver of this plasticity event because silencing of SOX2 in the LNCAP AR shRB1/TP53 tumors restores the sensitivity to enzalutamide in vivo, as well as the reduction of neuroendocrine markers.

The GEM model described by Zou et al. (2017) with Tpr53 and Pten losses (NPp53 mice) instead showed up-regulation of SOX11 and down-regulation of SOX2. Short Harpins RNA against SOX11 in NPp53 mice resulted in down-regulation of neuroendocrine markers as SYP and NSE. By analogy with neurogenesis, the authors reported that SOX2 and SOX11 were drivers of two different neuroendocrineassociated states in which SOX2 defined early events relative to lineage plasticity, whereas SOX11 was implicated in the final neuroendocrine differentiation process (Fig. 1). The NPp53 model elegantly showed the existence of the transdifferentiation process from a luminal/adenocarcinoma cell in a neuroendocrine, high proliferative cell. For this purpose, the authors used a lineage tracing in NPp53 mice with a R26R-yellow fluorescent protein (YFP) reporter allele expressed in luminal epithelial cells in adult prostate. With this system, the authors showed that SYP+ cells that arose after castration in NPp53 mice were all YFP-positive, demonstrating that neuroendocrine cells in CRPC$\mathrm{NE}$ tumors are of luminal origin.

\section{Patient-Derived Xenograft and Organoid Models}

Patient-derived xenograft (PDX) models represent another resource to study the CRPC-NE phenotype. Several groups have developed and characterized prostate cancer PDXs from multiple metastatic sites.

The LUCAP 49 PDX was derived from an omental metastasis of a patient with poorly differentiated neuroendocrine cancer. It is androgen insensitive, lacks expression of PSA and $\mathrm{AR}$, and overexpresses neuroendocrine markers. The tumor is highly aggressive and rapidly growing in mice with $>75 \%$ of nuclei positive for Ki67 (True et al. 2002).

The MDA PCA 144 PDX was derived from the salvage pelvic exenteration specimen (radical resection of the rectum, bladder, and reproductive organs) of a patient with castrate-resistant prostate carcinoma with small cell carcinoma 
L. Puca et al.

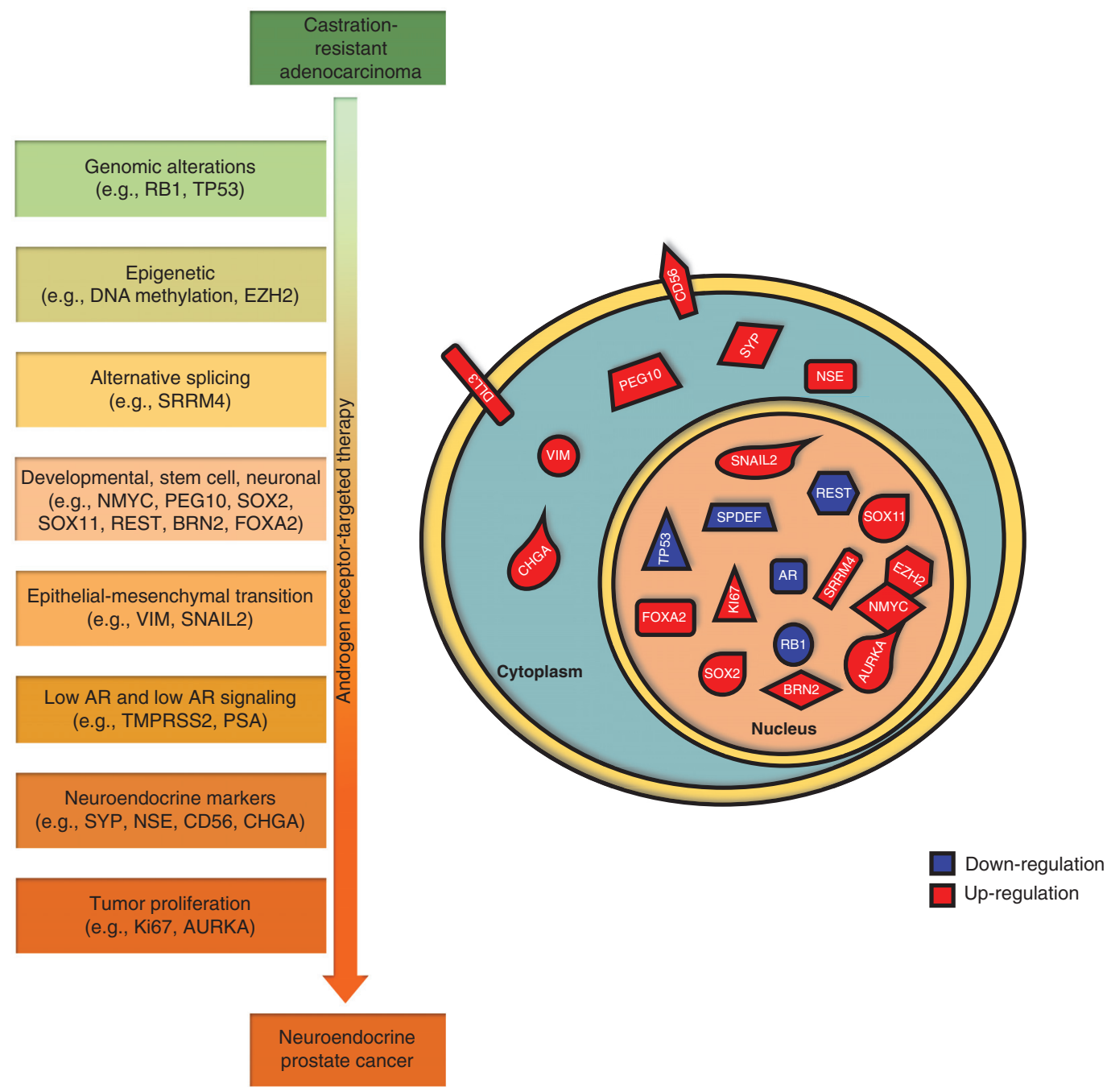

Figure 1. Schematic view of events leading to castration-resistant neuroendocrine prostate cancer (CRPC-NE). CRPC-NE arises as a resistant mechanism to androgen receptor-targeted therapy. Over time adenocarcinoma cells undergo a selective treatment pressure, acquiring multiple genomic (e.g., RB1 and TP53) and epigenomic (e.g., DNA methylation and high EZH2) alterations together with activation of different pathways. The slicing regulator SRRM4 leads to alternative splicing and therefore to a nonfunctional variant of the neuronal repressor repressor element silencing transcription factor (REST). Cells acquire stem and neuronal characteristics associated with up-regulation of N-MYC, PEG10, and BRN2, SOX2, and SOX11. Cells start transitioning toward a mesenchymal state with upregulation of VIM and SNAIL, drastically decreasing the expression of androgen receptor (AR) and androgenregulated genes, such as prostate-specific antigen (PSA), and up-regulating classical neuroendocrine markers (e.g., SYP (synaptophysin), CHGA (chromogranin A), and neuron-specific enolase [NSE]). This ultimately results in increased proliferation index and mitogen signaling, including up-regulation of AURKA (Aurora Kinase A) and KI67. 
features. The tumor strongly expresses chromogranin, synaptophysin, and CD56, and lacks expression of AR, PSA, prostatic acid phosphatase (PAP), and P504S ( $\alpha$-methylacyl-CoA racemase, AMACR) (Aparicio et al. 2011), and the TMPRSS2:ERG gene fusion is detected by FISH. This tumor displays a high proliferation index with Ki67 positivity in $>90 \%$ of nuclei.

The WISH-PC2 xenograft was derived from a transurethral resection of the prostate of a patient with Gleason score of $8(3+5)$ prostatic adenocarcinoma with NE differentiation. The tumors resemble the ones of the patient with expression of NE tumor markers chromogranin A, NSE, and synaptophysin, mutated form of TP53, expression of antiapoptotic protein BCL2, high proliferative index, and absence of AR, PSA, PAP, prostate stem cell antigen (PSCA), and prostate-specific membrane antigen (PSMA). This tumor has been serially passaged in vivo and is able to grow in castration conditions (Pinthus et al. 2000).

The LTL352 and LTL370 xenografts originated by engrafting prostate tumors from a urethral (LTL352) and penile metastasis (LTL370) under the kidney capsule of NOD/SCID mice. Tumors engrafted in mice retained the expression of neuroendocrine markers CGHA and SYP, were immunonegative for AR and PSA expression, and the TMPRSS2:ERG gene fusion was detected. Interestingly, another similar adenocarcinoma PDX model, LTL331 after host castration (termed LTL331R posttreatment) showed retention of genomic features of adenocarcinoma but histologic changes of CRPC-NE, expression of NE markers, and loss of $\mathrm{AR}$ and AR signaling, including PSA expression after host castration. Similar to patients with CRPCNE, LTL331R showed up-regulation of neuronal transcription factors, membrane ion receptors, secreted peptides, and up-regulation of epigenetic regulators (e.g., EZH2, CBX2) compared with the precastration adenocarcinoma LT331 model (Lin et al. 2014).

PDXs are advantageous as they retain the cellular heterogeneity, architectural and molecular characteristics of the original patient tumor. Although compared with GEM models they are immune deficient so they cannot be used to test compounds that interfere with the tumor immune microenvironment, PDXs represent a valuable model to evaluate the efficacy of targeted therapies.

In 2014, Karthaus et al., Gao et al., and Chua et al. further impacted the development of patient relevant preclinical models in prostate cancer through organoid models derived from normal prostate and metastatic prostate cancer biopsies (Chua et al., 2014; Gao et al. 2014; Karthaus et al. 2014). Organoids from normal prostate are three-dimensional (3D) cultures that recapitulate the organ multicellular structures in vitro by forming the basal and luminal layers of the normal prostate. Lineage-tracing showed that luminal cells can form organoids and generate basal cells in culture. Organoids from patient needle biopsies are 3D cultures of cancer cells, which act as "micrometasases" in culture. The 3D environment is generally obtained by embedding organoids in an extracellular matrix that sustains cancer growth in $3 \mathrm{D}$, and closely reflects the natural behavior of cancer tissue (Drost et al. 2016; Pauli et al. 2016). Patient-derived organoids retained the mutational profile of the corresponding original tumor and recapitulate the histological features of the tumor postengraftment in mice (Gao et al. 2014). Seven organoid lines were generated from metastatic biopsies (MSK PCA1-7) in Gao et al., and one of them displayed neuroendocrine features (MSK PCA4). MSK PCA4 derives from a pleural effusion of a patient who received ADT, bicalutamide, and docetaxel treatments. It displays small cell features with high proliferation index, negative for $A R$, and positive for synaptophysin staining in both 3D culture and when transplanted in mice. This model also displays PTEN and RB1 losses, and TP53 is mutated (Gao et al. 2014). Recently, newly established CRPC-NE organoid models were developed by Puca et al. (2017). These models retain the histological and molecular features of the corresponding patient over passages in culture, and were used in high-throughput drug screenings to nominate novel potential therapeutic targets for CRPCNE. These CRPC-NE models increase the number of in vitro models to study CRPC-NE pathogenesis and treatment hypotheses. 
L. Puca et al.

\section{EMERGING THERAPEUTIC TARGETS}

Early sequencing studies led to the discovery of N-MYC and AURKA as frequently overexpressed in CRPC-NE compared with prostate adenocarcinoma (Beltran et al. 2011; Mosquera et al. 2013). AURKA is a cell cycle kinase mainly localized at centrosome-regulating mitosis entry and formation of the mitotic spindle (Dominguez-Brauer et al. 2015). Similar to neuroblastoma, N-MYC is stabilized by AURKA in a catalytic activity-independent fashion, and this interaction prevents N-MYC proteasomal degradation in human neuroblastoma (Otto et al. 2009). This complex can be targeted using allosteric Aurora-A inhibitors (Brockmann et al. 2013; Gustafson et al. 2014). N-MYCoverexpressing prostate cancer models show enhanced sensitivity to selected aurora kinase inhibitors, resulting in destabilization of N-MYC protein and reduction of tumor burden in vivo (Beltran et al. 2011; Dardenne et al. 2016; Lee et al. 2016). These initial observations led to a Phase II clinical trial of the AURKA inhibitor alisertib for patients with de novo or treatmentrelated CRPC-NE (NCT01799278) (Beltran et al. 2016b), as well as further investigation of additional strategies to drug N-MYC and the N-MYC-AURKA complex in CRPC-NE.

Beyond its role in concert with AURKA, NMYC can also interact with AR and the histone methyltransferase $\mathrm{EZH} 2$ regulating the N-MYC and AR transcriptional program and driving neuroendocrine phenotype (Xu et al. 2012; Dardenne et al. 2016). Moreover, the expression of EZH2 is higher in CRPC-NE tumors compared with CRPC-Adeno (Beltran et al. 2016a), and the neuroendocrine cell line (NCI-H660) is more sensitive to EZH2 inhibitor than androgen-dependent LNCaP cells. EZH2 inhibitor treatment with 3-deazaneplanocin A (DZNep) resulted in AR expression and growth inhibition in AR (-) cell lines (Kleb et al. 2016). Hormonenaïve AR/PSA-positive adenocarcinoma PDXs (LTL331) that, on host castration, progress to a terminally differentiated CRPC-NE (LTL331R) show similar results with up-regulation of the epigenetic regulators $\mathrm{EZH} 2$ and $\mathrm{CBX} 2$ (Clermont et al. 2015). Cotreatment of castration- resistant cells derived from DKO tumor with EZH2 inhibitor and enzalutamide increased $\mathrm{AR}$ expression and reduced neuroendocrine markers, suggesting the usage of EZH2 inhibitor to revert this lineage transformation ( $\mathrm{Ku}$ et al. 2017). Phase 1 trials of EZH2 inhibitors are currently underway (NCT02082977, NCT01897571).

Bromodomain and extraterminal (BET) family proteins directly regulate the expression of MYC genes, and disruption of BET protein-binding silences MYC gene expression (Delmore et al. 2011). The inhibitor of BET, I-BET762, reduces MYC expression in LNCaP prostate cancer cell lines and in patient-derived tumor model with inhibition of cell growth and reduction of tumor burden in vivo (Wyce et al. 2013; Fu et al. 2015). BET inhibitors therefore may represent a potential approach and area of research for targeting $\mathrm{N}$ MYC-driven CRPC-NE.

The high rate of PTEN loss that occurs in CRPC-NE and prior studies implicating AKT1 expression as a driver of CRPC-NE together with N-MYC, as well as the ability of PTEN loss alone in GEM models to induce CRPC-Adeno (Floc'h 2012 Zou et al. 2017), suggest that the inhibition of PI3K/AKT/mechanistic target of rapamycin (mTOR) pathway may be an effective approach to inhibit tumor progression to CPRC-NE. Curcumin, a dietary component that can inhibit PI3K, has been shown to inhibit PIN formation in TRAMP mice (Li et al. 2007). Multiple clinical trials have been developed to target this pathway in CRPC patients with no specific arm for CPRC-NE patients.

Recent advances in CPRC-NE biology have provided new insights toward the development of novel drug targets, including BRN2 and SRRM4. Developing specific inhibitors targeting the activity of SRRM4 or BRN2 during antiandrogen targeted therapy could represent novel approaches for CPRC-NE treatment and warrant further investigation.

New insights into the treatment of CRPCNE have also come from small cell lung carcinoma studies. A recent study in small cell lung cancer (SCLC) identified the Delta-like ligand 3 (DLL3), a cell surface ligand for the Notch receptor, as highly overexpressed in SCLC patients and PDXs. An antibody targeting DLL3 linked to a 
potent cytotoxin results in internalization and complete and durable responses in SCLC PDX models (Saunders et al. 2015), and has shown promising results in patients (Rudin et al. 2016). A Phase I clinical trial (NCT02709889) is now open to evaluate the effect of this antibody-conjugated toxin (Rovalpituzumab-Tesirine) in DLL3-expressing solid tumors, including a dedicated CRPC-NE arm.

\section{CONCLUDING REMARKS}

Recent genomic landscape studies combined with preclinical observations and the development of new model systems have provided new insights into mechanisms driving treatment resistance in prostate cancer. Neuroendocrine prostate cancer is a complex androgen-independent phenotype that may arise de novo or in later stages of prostate cancer progression as a mechanism of treatment resistance from an adenocarcinoma precursor. Ongoing efforts are focused on establishing targeted and cotargeting approaches based on the identified molecular drivers of CRPC-NE.

\section{ACKNOWLEDGMENTS}

L.P. and H.B. are supported by the Prostate Cancer Foundation (PCF), and L.P. received a 2016 Lori-Milken PCF Young Investigator Award. L.P. is also supported by an American-Italian Cancer Foundation Fellowship. H.B. has received research funding from Millenium, Astellas, Janssen, and Abbvie Stemcentryx.

\section{REFERENCES}

Abdul M, Anezinis PE, Logothetis CJ, Hoosein NM. 1994. Growth inhibition of human prostatic carcinoma cell lines by serotonin antagonists. Anticancer Res 14: 12151220.

Adam RM, Kim J, Lin J, Orsola A, Zhuang L, Rice DC, Freeman MR, Kim J, Adam RM, Freeman MR, et al. 2002. Heparin-binding epidermal growth factor-like growth factor stimulates androgen-independent prostate tumor growth and antagonizes androgen receptor function. Endocrinology 143: 4599-4608.

Adamo P, Ladomery MR. 2016. The oncogene ERG: A key factor in prostate cancer. Oncogene 35: 403-414.
Akamatsu S, Wyatt AW, Lin D, Lysakowski S, Zhang F, Kim S, Tse C, Wang K, Mo F, Haegert A, et al. 2015. The placental gene PEG10 promotes progression of neuroendocrine prostate cancer. Cell Rep. 12: 922-936.

Aparicio A, Tzelepi V, Araujo JC, Guo CC, Liang S, Troncoso P, Logothetis CJ, Navone NM, Maity SN. 2011. Neuroendocrine prostate cancer xenografts with large-cell and small-cell features derived from a single patient's tumor: Morphological, immunohistochemical, and gene expression profiles. Prostate 71: 846-856.

Armenia J, Wankowicz SAM, Liu D, Gao J, Kundra R, Reznik E, Chatila WK, Chakravarty D, Han GC, Coleman I, et al. 2018. The long tail of oncogenic drivers in prostate cancer. Nat Genet 2018: doi: 10.1038/s41588-018-0078-z.

Ballas N, Mandel G, Ballas N, Grunseich C, Lu DD, Speh JC, Mandel G, Lunyak VV, Rosenfeld MG, Otto SJ, et al. 2005. The many faces of REST oversee epigenetic programming of neuronal genes. Curr Opin Neurobiol 15: 500-506.

Beltran H, Rickman DS, Park K, Chae SS, Sboner A, MacDonald TY, Wang Y, Sheikh KL, Terry S, Tagawa ST, et al. 2011. Molecular characterization of neuroendocrine prostate cancer and identification of new drug targets. Cancer Discov 1: 487-495.

Beltran H, Prandi D, Mosquera JM, Benelli M, Puca L, Cyrta J, Marotz C, Giannopoulou E, Chakravarthi BV, Varambally S, et al. 2016a. Divergent clonal evolution of castration-resistant neuroendocrine prostate cancer. Nat Med 22: 298-305.

Beltran H, Danila D, Montgomery B, Szmulewitz R, Vaishampayan U, Armstrong A, Stein M, Hoimes C, Pinski J, Scher H, et al. 2016b. A phase 2 study of the aurora kinase A inhibitor alisertib for patients with neuroendocrine prostate cancer (NEPC). Ann Oncol 27: 1-36.

Bishop JL, Thaper D, Vahid S, Davies A, Ketola K, Kuruma H, Jama R, Nip KM, Angeles A, Johnson F, et al. 2016. The master neural transcription factor BRN2 is an androgen receptor suppressed driver of neuroendocrine differentiation in prostate cancer. Cancer Discov 22: R165-R182.

Bluemn EG, Coleman IM, Lucas JM, Coleman RT, Hernandez-Lopez S, Tharakan R, Bianchi-Frias D, Dumpit RF, Kaipainen A, Corella AN, et al. 2017. Androgen receptor pathway-independent prostate cancer is sustained through FGF signaling. Cancer Cell 32: 474-489.

Bonkhoff H, Wernert N, Dhom G, Remberger K, Bonkhoff H, Stein U, Remberger K. 1991. Relation of endocrineparacrine cells to cell proliferation in normal, hyperplastic, and neoplastic human prostate. Prostate 19: 91-98.

Bonkhoff H, Stein U, Remberger K, Bonkhoff H, Bonkhoff H, Wernert N, Dhom G, Remberger K, Nakada SY, di Sant'Agnese PA, et al. 1995. Endocrine-paracrine cell types in the prostate and prostatic adenocarcinoma are postmitotic cells. Hum Pathol 26: 167-170.

Brockmann M, Poon E, Berry T, Carstensen A, Deubzer HE, Rycak L, Jamin Y, Thway K, Robinson SP, Roels F, et al. 2013. Small molecule inhibitors of aurora-a induce proteasomal degradation of N-MYC in childhood neuroblastoma. Cancer Cell 24: 75-89.

Brodeur GM, Seeger RC, Schwab M, Varmus HE, Bishop JM, Otto T, Horn S, Brockmann M, Eilers U, Schuttrumpf L, et al. 1984. Amplification of N-MYC in untreated human neuroblastomas correlates with advanced disease stage. Science 224: 1121-1124. 
L. Puca et al.

Cheng XH, Black M, Ustiyan V, Le T, Fulford L, Sridharan A Medvedovic M, Kalinichenko VV, Whitsett JA, Kalin TV. 2014. SPDEF inhibits prostate carcinogenesis by disrupting a positive feedback loop in regulation of the Foxml oncogene. PLoS Genet 10: e1004656.

Chiaverotti T, Couto SS, Donjacour A, Mao JH, Nagase H, Cardiff RD, Cunha GR, Balmain A. 2008. Dissociation of epithelial and neuroendocrine carcinoma lineages in the transgenic adenocarcinoma of mouse prostate model of prostate cancer. Am J Pathol 172: 236-246.

Chlenski A, Nakashiro K, Ketels KV, Korovaitseva GI, Oyasu R. 2001. Androgen receptor expression in androgen-independent prostate cancer cell lines. Prostate 47: 66-75.

Chua CW, Shibata M, Lei M, Toivanen R, Barlow LJ, Bergren SK, Badani KK, McKiernan JM, Benson MC, Hibshoosh $\mathrm{H}$, et al. 2014. Single luminal epithelial progenitors can generate prostate organoids in culture. Nat Cell Biol 16: 951-961.

Ciarlo M, Benelli R, Barbieri O, Minghelli S, Barboro P, Balbi C, Ferrari N, Uysal-Onganer P, Kawano Y, Caro M, et al. 2012. Regulation of neuroendocrine differentiation by $\mathrm{AKT} / \mathrm{hnRNPK} / \mathrm{AR} / \beta$-catenin signaling in prostate cancer cells. Int J Cancer 131: 582-590.

Clermont PL, Lin D, Crea F, Wu R, Xue H, Wang Y, Thu KL, Lam WL, Collins CC, Wang Y, et al. 2015. Polycombmediated silencing in neuroendocrine prostate cancer. Clin Epigenetics 7: 40.

Conley-LaComb MK, Saliganan A, Kandagatla P, Chen YQ, Cher ML, Chinni SR. 2013. PTEN loss mediated Akt activation promotes prostate tumor growth and metastasis via CXCL12/CXCR4 signaling. Mol Cancer 12: 85.

Courel M, El Yamani FZ, Alexandre D, El Fatemi H, Delestre C, Montero-Hadjadje M, Tazi F, Amarti A, Magoul R, Chartrel N, et al. 2014. Secretogranin II is overexpressed in advanced prostate cancer and promotes the neuroendocrine differentiation of prostate cancer cells. Eur J Cancer 50: 3039-3049.

Cox ME, Deeble PD, Lakhani S, Parsons SJ. 1999. Acquisition of neuroendocrine characteristics by prostate tumor cells is reversible: Implications for prostate cancer progression. Cancer Res 59: 3821-3830.

Dang CV. 2012. MYC on the path to cancer. Cell 149: 22-35.

Danza G, Di Serio C, Rosati F, Lonetto G, Sturli N, Kacer D, Pennella A, Ventimiglia G, Barucci R, Piscazzi A, et al. 2012. Notch signaling modulates hypoxia-induced neuroendocrine differentiation of human prostate cancer cells. Mol Cancer Res 10: 230-238

Dardenne E, Beltran H, Benelli M, Gayvert K, Berger A, Puca L, Cyrta J, Sboner A, Noorzad Z, MacDonald T, et al. 2016. N-MYC induces an EZH2-mediated transcriptional program driving neuroendocrine prostate cancer. Cancer Cell 30: 563-577.

Delmore JE, Issa GC, Lemieux ME, Rahl PB, Shi J, Jacobs HM, Kastritis E, Gilpatrick T, Paranal RM, Qi J, et al. 2011. BET bromodomain inhibition as a therapeutic strategy to target c-Myc. Cell 146: 904-917.

Dizeyi N, Konrad L, Bjartell A, Wu H, Gadaleanu V, Hansson J, Helboe L, Abrahamsson PA. 2002. Localization and mRNA expression of somatostatin receptor subtypes in human prostatic tissue and prostate cancer cell lines. Urol Oncol 7: 91-98.
Dominguez-Brauer C, Thu KL, Mason JM, Blaser H, Bray MR, Mak TW, Dang CV. 2015. Targeting mitosis in cancer: Emerging strategies. Mol Cell 60: 524-536.

Drost J, Karthaus WR, Gao D, Driehuis E, Sawyers CL, Chen Y, Clevers H. 2016. Organoid culture systems for prostate epithelial and cancer tissue. Nat Protoc 11: 347-358.

Epstein JI, Amin MB, Beltran H, Lotan TL, Mosquera JM, Reuter VE, Robinson BD, Troncoso P, Rubin MA. 2014. Proposed morphologic classification of prostate cancer with neuroendocrine differentiation. Am J Surg Pathol 38: 756-767.

Floc'h N, Kinkade CW, Kobayashi T, Aytes A, Lefebvre C, Mitrofanova A, Cardiff RD, Califano A, Shen MM, AbateShen C. 2012. Dual targeting of the Akt/mTOR signaling pathway inhibits castration-resistant prostate cancer in a genetically engineered mouse model. Cancer Res 72: 4483-4493.

Fu LL, Tian M, Li X, Li JJ, Huang J, Ouyang L, Zhang Y, Liu B. 2015. Inhibition of BET bromodomains as a therapeutic strategy for cancer drug discovery. Oncotarget 6: 55015516.

Gao D, Vela I, Sboner A, Iaquinta PJ, Karthaus WR, Gopalan A, Dowling C, Wanjala JN, Undvall EA, Arora VK, et al. 2014. Organoid cultures derived from patients with advanced prostate cancer. Cell 159: 176-187.

George J, Lim JS, Jang SJ, Cun Y, Ozretic L, Kong G, Leenders F, Lu X, Fernandez-Cuesta L, Bosco G, et al. 2015. Comprehensive genomic profiles of small cell lung cancer. Nature 524: 47-53.

Gingrich JR, Barrios RJ, Morton RA, Boyce BF, DeMayo FJ, Finegold MJ, Angelopoulou R, Rosen JM, Greenberg NM. 1996. Metastatic prostate cancer in a transgenic mouse. Cancer Res 56: 4096-4102.

Greenberg NM, DeMayo F, Finegold MJ, Medina D, Tilley WD, Aspinall JO, Cunha GR, Donjacour AA, Matusik RJ, Rosen JM. 1995. Prostate cancer in a transgenic mouse. Proc Natl Acad Sci 92: 3439-3443.

Gustafson WC, Meyerowitz JG, Nekritz EA, Chen J, Benes C, Charron E, Simonds EF, Seeger R, Matthay KK, Hertz NT, et al. 2014. Drugging MYCN through an allosteric transition in Aurora kinase A. Cancer Cell 26: 414-427.

Hansel DE, Nakayama M, Luo J, Abukhdeir AM, Park BH, Bieberich CJ, Hicks JL, Eisenberger M, Nelson WG Mostwin JL, et al. 2009. Shared TP53 gene mutation in morphologically and phenotypically distinct concurrent primary small cell neuroendocrine carcinoma and adenocarcinoma of the prostate. Prostate 69: 603-609.

Harhaj EW, Dixit VM. 2011. Deubiquitinases in the regulation of NF- $\mathrm{KB}$ signaling. Cell Res 21: 22-39.

Jongsma J, Oomen MH, Noordzij MA, Romijn JC, van Der Kwast TH, Schroder FH, van Steenbrugge GJ. 2000. Androgen-independent growth is induced by neuropeptides in human prostate cancer cell lines. Prostate 42: 34-44.

Kaighn ME, Narayan KS, Ohnuki Y, Lechner JF, Jones LW. 1979. Establishment and characterization of a human prostatic carcinoma cell line (PC-3). Invest Urol 17: 16-23.

Karthaus WR, Iaquinta PJ, Drost J, Gracanin A, van Boxtel R, Wongvipat J, Dowling CM, Gao D, Begthel H, Sachs N, et al. 2014. Identification of multipotent luminal progenitor cells in human prostate organoid cultures. Cell 159: 163-175. 
Kazzaz BA. 1974. Argentaffin and argyrophil cells in the prostate. J Pathol 112: 189-193.

Kleb B, Estecio MR, Zhang J, Tzelepi V, Chung W, Jelinek J, Navone NM, Tahir S, Marquez VE, Issa JP, et al. 2016. Differentially methylated genes and androgen receptor re-expression in small cell prostate carcinomas. Epigenetics 11: 184-193.

Knoepfler PS, Cheng PF, Eisenman RN. 2002. N-MYC is essential during neurogenesis for the rapid expansion of progenitor cell populations and the inhibition of neuronal differentiation. Genes Dev 16: 2699-2712.

Kwabi-Addo B, Giri D, Schmidt K, Podsypanina K, Parsons R, Greenberg N, Ittmann M. 2001. Haploinsufficiency of the Pten tumor suppressor gene promotes prostate cancer progression. Proc Natl Acad Sci 98: 11563-11568.

Ku SY, Rosario S, Wang Y, Mu P, Seshadri M, Goodrich ZW, Goodrich MM, Labbe DP, Gomez EC, Wang J, et al. 2017. $R b 1$ and $\operatorname{Trp} 53$ cooperate to suppress prostate cancer lineage plasticity, metastasis, and antiandrogen resistance. Science 355: 78-83.

Lapuk AV, Wu C, Wyatt AW, McPherson A, McConeghy BJ, Brahmbhatt S, Mo F, Zoubeidi A, Anderson S, Bell RH, et al. 2012. From sequence to molecular pathology, and a mechanism driving the neuroendocrine phenotype in prostate cancer. J Pathol 227: 286-297.

Lee JK, Phillips JW, Smith BA, Park JW, Stoyanova T, McCaffrey EF, Baertsch R, Sokolov A, Meyerowitz JG, Mathis C, et al. 2016. N-MYC drives neuroendocrine prostate cancer initiated from human prostate epithelial cells. Cancer Cell 29: 536-547.

Li M, Zhang Z, Hill DL, Wang H, Zhang R, Saunders LR, Bankovich AJ, Anderson WC, Aujay MA, Bheddah S, et al. 2007. Curcumin, a dietary component, has anticancer, chemosensitization, and radiosensitization effects by down-regulating the MDM2 oncogene through the PI3K/mTOR/ETS2 pathway. Cancer Res 67: 1988-1996.

Li Z, Sun Y, Chen X, Squires J, Nowroozizadeh B, Liang C, Huang J. 2015. p53 mutation directs AURKA overexpression via miR-25 and FBXW7 in prostatic small cell neuroendocrine carcinoma. Mol Cancer Res 13: 584-591.

Li Y, Donmez N, Sahinalp C, Xie N, Wang Y, Xue H, Mo F, Beltran H, Gleave M, Wang Y, et al. 2017. SRRM4 drives neuroendocrine trans-differentiation of prostate adenocarcinoma under androgen receptor pathway inhibition. Eur Urol 31: 1124-1131.

Liang H, Studach L, Hullinger RL, Xie J, Andrisani OM. 2014. Down-regulation of RE-1 silencing transcription factor (REST) in advanced prostate cancer by hypoxiainduced miR-106b 25. Exp Cell Res 320: 188-199.

Lin D, Wyatt AW, Xue H, Wang Y, Dong X, Haegert A, Wu R, Brahmbhatt S, Mo F, Jong L, et al. 2014. High fidelity patient-derived xenografts for accelerating prostate cancer discovery and drug development. Cancer Res 74: 1272-1283.

Lin TP, Chang YT, Lee SY, Campbell M, Wang TC, Shen SH, Chung HJ, Chang YH, Chiu AW, Pan CC, et al. 2016. REST reduction is essential for hypoxia-induced neuroendocrine differentiation of prostate cancer cells by activating autophagy signaling. Oncotarget 7: 26137-26151.

Lotan TL, Gupta NS, Wang W, Toubaji A, Haffner MC, Chaux A, Hicks JL, Meeker AK, Bieberich CJ, De Marzo AM, et al. 2011. ERG gene rearrangements are common in prostatic small cell carcinomas. Mod Pathol 24: 820828.

Marchiani S, Tamburrino L, Nesi G, Paglierani M, Gelmini S, Orlando C, Maggi M, Forti G, Baldi E. 2010. Androgenresponsive and -unresponsive prostate cancer cell lines respond differently to stimuli inducing neuroendocrine differentiation. Int J Androl 33: 784-793.

Markwalder R, Reubi JC. 1999. Gastrin-releasing peptide receptors in the human prostate: Relation to neoplastic transformation. Cancer Res 59: 1152-1159.

Massoumi R, Sun SC, Cheng XH, Black M, Ustiyan V, Le T, Fulford L, Sridharan A, Medvedovic M, Kalinichenko VV, et al. 2010. Ubiquitin chain cleavage: CYLD at work. Trends Biochem Sci 35: 392-399.

McKeithen D, Graham T, Chung LW, Odero-Marah V. 2010. Snail transcription factor regulates neuroendocrine differentiation in LNCaP prostate cancer cells. Prostate 70: 982-992.

Meder L, Konig K, Ozretic L, Schultheis AM, Ueckeroth F, Ade CP, Albus K, Boehm D, Rommerscheidt-Fuss U, Florin A, et al. 2016. NOTCH, ASCL1, p53 and RB alterations define an alternative pathway driving neuroendocrine and small cell lung carcinomas. Int J Cancer 138: 927-938.

Mertz KD, Setlur SR, Dhanasekaran SM, Demichelis F, Perner S, Tomlins S, Tchinda J, Laxman B, Vessella RL, Beroukhim R, et al. 2007. Molecular characterization of TMPRSS2-ERG gene fusion in the NCI-H660 prostate cancer cell line: A new perspective for an old model. Neoplasia 9: 200-206.

Mosquera JM, Mehra R, Regan MM, Perner S, Genega EM, Bueti G, Shah RB, Gaston S, Tomlins SA, Wei JT, et al. 2009. Prevalence of TMPRSS2-ERG fusion prostate cancer among men undergoing prostate biopsy in the United States. Clin Cancer Res 15: 4706-4711.

Mosquera JM, Beltran H, Park K, MacDonald TY, Robinson BD, Tagawa ST, Perner S, Bismar TA, Erbersdobler A, Dhir R, et al. 2013. Concurrent AURKA and MYCN gene amplifications are harbingers of lethal treatmentrelated neuroendocrine prostate cancer. Neoplasia 15: $1-10$.

Mounir Z, Lin F, Lin VG, Korn JM, Yu Y, Valdez R, Aina $\mathrm{OH}$, Buchwalter G, Jaffe AB, Korpal M, et al. 2015. TMPRSS2:ERG blocks neuroendocrine and luminal cell differentiation to maintain prostate cancer proliferation. Oncogene 34: 3815-3825.

Mu P, Zhang Z, Benelli M, Karthaus WR, Hoover E, Chen CC, Wongvipat J, Ku SY, Gao D, Cao Z, et al. 2017. SOX2 promotes lineage plasticity and antiandrogen resistance in TP53- and RB1-deficient prostate cancer. Science 355: $84-88$.

Nakada SY, di Sant'Agnese PA, Moynes RA, Hiipakka RA, Liao S, Cockett AT, Abrahamsson PA. 1993. The androgen receptor status of neuroendocrine cells in human benign and malignant prostatic tissue. Cancer Res 53: 1967-1970.

Otto T, Horn S, Brockmann M, Eilers U, Schuttrumpf L, Popov N, Kenney AM, Schulte JH, Beijersbergen R, Christiansen H, et al. 2009. Stabilization of N-MYC is a critical function of Aurora A in human neuroblastoma. Cancer Cell 15: 67-78. 
L. Puca et al.

Parimi V, Goyal R, Poropatich K, Yang XJ. 2014. Neuroendocrine differentiation of prostate cancer: A review. Am J Clin Exp Urol 2: 273-285.

Park K, Dalton JT, Narayanan R, Barbieri CE, Hancock ML, Bostwick DG, Steiner MS, Rubin MA. 2014. TMPRSS2: $E R G$ gene fusion predicts subsequent detection of prostate cancer in patients with high-grade prostatic intraepithelial neoplasia. J Clin Oncol 32: 206-211.

Park JW, Lee JK, Witte ON, Huang J. 2017. FOXA2 is a sensitive and specific marker for small cell neuroendocrine carcinoma of the prostate. Mod Pathol 30: 12621272.

Patrawala L, Calhoun T, Schneider-Broussard R, Li H, Bhatia B, Tang S, Reilly JG, Chandra D, Zhou J, Claypool K, et al. 2006. Highly purified CD $44^{+}$prostate cancer cells from xenograft human tumors are enriched in tumorigenic and metastatic progenitor cells. Oncogene 25: 1696-1708.

Pauli C, Puca L, Mosquera JM, Robinson BD, Beltran H, Rubin MA, Rao RA. 2016. An emerging role for cytopathology in precision oncology. Cancer Cytopathol 124: 167-173.

Pinthus JH, Waks T, Schindler DG, Harmelin A, Said JW, Belldegrun A, Ramon J, Eshhar Z. 2000. WISH-PC2: A unique xenograft model of human prostatic small cell carcinoma. Cancer Res 60: 6563-6567.

Puca L, Bareja R, Shaw R, Karthaus W, Gao D, Pauli C, Miguel Mosquera J, Cyrta J, Rosati R, Rao R, et al. 2017. Abstract 992: Patient-derived tumor organoids of neuroendocrine prostate cancer, AACR Annual Meeting, Vol. 77.

Qi J, Nakayama K, Cardiff RD, Borowsky AD, Kaul K, Williams R, Krajewski S, Mercola D, Carpenter PM, Bowtell D, et al. 2010. Siah2-dependent concerted activity of HIF and FoxA2 regulates formation of neuroendocrine phenotype and neuroendocrine prostate tumors. Cancer Cell 18: $23-38$.

Quiros-Gonzalez I, Sainz RM, Hevia D, Mayo JC, Courel M, El Yamani FZ, Alexandre D, El Fatemi H, Delestre C, Montero-Hadjadje M, et al. 2011. MnSOD drives neuroendocrine differentiation, androgen independence, and cell survival in prostate cancer cells. Free Radic Biol Med 50: 525-536.

Rapa I, Volante M, Migliore C, Farsetti A, Berruti A, Vittorio Scagliotti G, Giordano S, Papotti M, Adam RM, Kim J, et al. 2013. Human ASH-1 promotes neuroendocrine differentiation in androgen deprivation conditions and interferes with androgen responsiveness in prostate cancer cells. Prostate 73: 1241-1249.

Robinson D, Van Allen EM, Wu YM, Schultz N, Lonigro RJ, Mosquera JM, Montgomery B, Taplin ME, Pritchard CC, Attard G, et al. 2015. Integrative clinical genomics of advanced prostate cancer. Cell 161: 1215-1228.

Rudin CM, Pietanza MC, Bauer TM, Ready N, Morgensztern D, Glisson BS, Byers LA, Johnson ML, Burris HA III, Robert F, et al. 2016. Rovalpituzumab tesirine, a DLL3targeted antibody-drug conjugate, in recurrent small-cell lung cancer: A first-in-human, first-in-class, open-label, phase 1 study. Lancet Oncol 18: 42-51.

Salido M, Vilches J, Lopez A. 2000. Neuropeptides bombesin and calcitonin induce resistance to etoposide induced apoptosis in prostate cancer cell lines. Histol Histopathol 15: 729-738.
Saunders LR, Bankovich AJ, Anderson WC, Aujay MA, Bheddah S, Black K, Desai R, Escarpe PA, Hampl J, Laysang A, et al. 2015. A DLL3-targeted antibody-drug conjugate eradicates high-grade pulmonary neuroendocrine tumor-initiating cells in vivo. Sci Transl Med 7: 302ra136.

Siegel RL, Miller KD, Jemal A. 2016. Cancer statistics, 2016. CA Cancer J Clin 66: 7-30.

Simon RA, di Sant'Agnese PA, Huang LS, Xu H, Yao JL, Yang Q, Liang S, Liu J, Yu R, Cheng L, et al. 2009. CD44 expression is a feature of prostatic small cell carcinoma and distinguishes it from its mimickers. Hum Pathol 40: 252-258.

Smith BA, Sokolov A, Uzunangelov V, Baertsch R, Newton Y, Graim K, Mathis C, Cheng D, Stuart JM, Witte ON. 2015. A basal stem cell signature identifies aggressive prostate cancer phenotypes. Proc Natl Acad Sci 112: E6544-E6552.

Sramkoski RM, Pretlow TG II, Giaconia JM, Pretlow TP, Schwartz S, Sy MS, Marengo SR, Rhim JS, Zhang D, Jacobberger JW. 1999. A new human prostate carcinoma cell line, 22Rv1. In Vitro Cell Dev Biol Anim 35: 403-409.

Sun L, Gao J, Huo L, Sun X, Shi X, Liu M, Li D, Zhang C, Zhou J, Sun Y, et al. 2010. Tumour suppressor CYLD is a negative regulator of the mitotic kinase Aurora-B. J Pathol 221: 425-432.

Sun Y, Wang BE, Leong KG, Yue P, Li L, Jhunjhunwala S, Chen D, Seo K, Modrusan Z, Gao WQ, et al. 2012. Androgen deprivation causes epithelial-mesenchymal transition in the prostate: Implications for androgen-deprivation therapy. Cancer Res 72: 527-536.

Svensson C, Ceder J, Iglesias-Gato D, Chuan YC, Pang ST, Bjartell A, Martinez RM, Bott L, Helczynski L, Ulmert D, et al. 2014. REST mediates androgen receptor actions on gene repression and predicts early recurrence of prostate cancer. Nucleic Acids Res 42: 999-1015.

Tai S, Sun Y, Squires JM, Zhang H, Oh WK, Liang CZ, Huang J. 2011. PC3 is a cell line characteristic of prostatic small cell carcinoma. Prostate 71: 1668-1679.

Tan HL, Sood A, Rahimi HA, Wang W, Gupta N, Hicks J, Mosier S, Gocke CD, Epstein JI, Netto GJ, et al. 2014. Rb loss is characteristic of prostatic small cell neuroendocrine carcinoma. Clin Cancer Res 20: 890-903.

Tang Y, Wang L, Goloubeva O, Khan MA, Lee D, Hussain A, Zhou Z, Flesken-Nikitin A, Corney DC, Wang W, et al. 2009. The relationship of neuroendocrine carcinomas to anti-tumor therapies in TRAMP mice. Prostate 69: 17631773.

Terry S, Beltran H. 2014. The many faces of neuroendocrine differentiation in prostate cancer progression. Front Oncol 4: 60 .

Tomlins SA, Rhodes DR, Perner S, Dhanasekaran SM, Mehra R, Sun XW, Varambally S, Cao X, Tchinda J, Kuefer R, et al. 2005. Recurrent fusion of TMPRSS2 and ETS transcription factor genes in prostate cancer. Science 310: 644-648.

True LD, Buhler K, Quinn J, Williams E, Nelson PS, Clegg N, Macoska JA, Norwood T, Liu A, Ellis W, et al. 2002. A neuroendocrine/small cell prostate carcinoma xenograftLuCaP 49. Am J Pathol 161: 705-715.

Tsai H, Morais CL, Alshalalfa M, Tan HL, Haddad Z, Hicks J, Gupta N, Epstein JI, Netto GJ, Isaacs WB, et al. 2015. Cyclin D1 loss distinguishes prostatic small-cell carcino- 
ma from most prostatic adenocarcinomas. Clin Cancer Res 21: 5619-5629.

Tsui KH, Lin YH, Chung LC, Chuang ST, Feng TH, Chiang KC, Chang PL, Yeh CJ, Juang HH, Sun Y, et al. 2016. Prostate-derived ets factor represses tumorigenesis and modulates epithelial-to-mesenchymal transition in bladder carcinoma cells. Cancer Lett 375: 142-151.

Uysal-Onganer P, Kawano Y, Caro M, Walker MM, Diez S, Darrington RS, Waxman J, Kypta RM. 2010. Wnt-11 promotes neuroendocrine-like differentiation, survival and migration of prostate cancer cells. Mol Cancer 9: 55.

Williamson SR, Zhang S, Yao JL, Huang J, Lopez-Beltran A, Shen S, Osunkoya AO, MacLennan GT, Montironi R, Cheng L. 2011. ERG-TMPRSS2 rearrangement is shared by concurrent prostatic adenocarcinoma and prostatic small cell carcinoma and absent in small cell carcinoma of the urinary bladder: Evidence supporting monoclonal origin. Mod Pathol 24: 1120-1127.

Wright ME, Tsai MJ, Aebersold R, Zhu Y, Liu C, Cui Y, Nadiminty N, Lou W, Gao AC, Chang PC, et al. 2003. Androgen receptor represses the neuroendocrine transdifferentiation process in prostate cancer cells. Mol Endocrinol 17: 1726-1737.

Wu C, Huang J, Ciarlo M, Benelli R, Barbieri O, Minghelli S, Barboro P, Balbi C, Ferrari N, Uysal-Onganer P, et al. 2007. Phosphatidylinositol 3-kinase-AKT-mammalian target of rapamycin pathway is essential for neuroendocrine differentiation of prostate cancer. J Biol Chem 282: 3571-3583.

Wyce A, Degenhardt Y, Bai Y, Le B, Korenchuk S, Crouthame MC, McHugh CF, Vessella R, Creasy CL, Tummino PJ, et al. 2013. Inhibition of BET bromodomain proteins as a therapeutic approach in prostate cancer. Oncotarget 4: 2419-2429.
Xu K, Wu ZJ, Groner AC, He HH, Cai C, Lis RT, Wu X, Stack EC, Loda M, Liu T, et al. 2012. EZH2 oncogenic activity in castration-resistant prostate cancer cells is polycomb-independent. Science 338: 1465-1469.

Yamasaki M, Nomura T, Sato F, Mimata H, Danza G, Di Serio C, Rosati F, Lonetto G, Sturli N, Kacer D, et al. 2013. Chronic hypoxia induces androgen-independent and invasive behavior in LNCaP human prostate cancer cells. Urol Oncol 31: 1124-1131.

Zhang XQ, Kondrikov D, Yuan TC, Lin FF, Hansen J, Lin MF. 2003. Receptor protein tyrosine phosphatase alpha signaling is involved in androgen depletion-induced neuroendocrine differentiation of androgen-sensitive $\mathrm{LNCaP}$ human prostate cancer cells. Oncogene 22: 6704-6716.

Zhang X, Coleman IM, Brown LG, True LD, Kollath L, Lucas JM, Lam HM, Dumpit R, Corey E, Chery L, et al. 2015. SRRM4 Expression and the loss of REST activity may promote the emergence of the neuroendocrine phenotype in castration-resistant prostate cancer. Clin Cancer Res 21: 4698-4708.

Zhou Z, Flesken-Nikitin A, Corney DC, Wang W, Goodrich DW, Roy-Burman P, Nikitin AY. 2006. Synergy of p53 and $\mathrm{Rb}$ deficiency in a conditional mouse model for metastatic prostate cancer. Cancer Res 66: 7889-7898.

Zhu Y, Liu C, Cui Y, Nadiminty N, Lou W, Gao AC, Lapuk AV, Wu C, Wyatt AW, McPherson A, et al. 2014. Interleukin-6 induces neuroendocrine differentiation (NED) through suppression of RE-1 silencing transcription factor (REST). Prostate 74: 1086-1094.

Zou M, Toivanen R, Mitrofanova A, Floch N, Hayati S, Sun Y, Le Magnen C, Chester D, Mostaghel EA, Califano A, et al. 2017. Trans-differentiation as a mechanism of treatment resistance in a mouse model of castration-resistant prostate cancer. Cancer Discov 7: 736-749. 


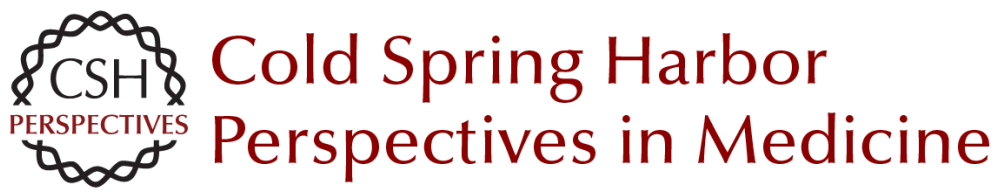

\title{
Neuroendocrine Differentiation in Prostate Cancer: Emerging Biology, Models, and Therapies
}

\author{
Loredana Puca, Panagiotis J. Vlachostergios and Himisha Beltran
}

Cold Spring Harb Perspect Med 2019; doi: 10.1101/cshperspect.a030593 originally published online May 29, 2018

\section{Subject Collection Prostate Cancer}

Anatomic and Molecular Imaging in Prostate

Cancer

Eric T. Miller, Amirali Salmasi and Robert E. Reiter

The Epidemiology of Prostate Cancer

Claire H. Pernar, Ericka M. Ebot, Kathryn M. Wilson, et al.

Prostate Stem Cells and Cancer Stem Cells Jia J. Li and Michael M. Shen

Prostate Cancer Epigenetics: From Basic

Mechanisms to Clinical Implications

Srinivasan Yegnasubramanian, Angelo M. De

Marzo and William G. Nelson

The Genomics of Prostate Cancer: A Historic

Perspective

Mark A. Rubin and Francesca Demichelis

Neuroendocrine Differentiation in Prostate

Cancer: Emerging Biology, Models, and Therapies Loredana Puca, Panagiotis J. Vlachostergios and Himisha Beltran

DNA Damage Response in Prostate Cancer Matthew J. Schiewer and Karen E. Knudsen

Transcriptional Regulation in Prostate Cancer David P. Labbé and Myles Brown
New Opportunities for Targeting the Androgen

Receptor in Prostate Cancer Margaret M. Centenera, Luke A. Selth, Esmaeil Ebrahimie, et al.

Prostate Cancer Research at the Crossroads Michael M. Shen and Mark A. Rubin

Immunotherapy for Prostate Cancer Nicholas J. Venturini and Charles G. Drake

Molecular Pathology of High-Grade Prostatic Intraepithelial Neoplasia: Challenges and Opportunities Levent Trabzonlu, Ibrahim Kulac, Qizhi Zheng, et al.

Metastases in Prostate Cancer Federico La Manna, Sofia Karkampouna, Eugenio Zoni, et al.

Genetically Engineered Mouse Models of Prostate Cancer in the Postgenomic Era Juan M. Arriaga and Cory Abate-Shen

Molecular Biomarkers in the Clinical Management of Prostate Cancer Aaron M. Udager and Scott A. Tomlins

Metabolic Vulnerabilities of Prostate Cancer:

Diagnostic and Therapeutic Opportunities Giorgia Zadra and Massimo Loda

For additional articles in this collection, see http://perspectivesinmedicine.cshlp.org/cgi/collection/ 